\title{
The Methods for Forming Artistic and Creative Experience of the Future Choreography Teacher in the Process of Professional Education
}

\author{
Maksymenko Vira \\ Lecturer, \\ Nizhyn Mykola Gogol State University \\ Shcholokova Olga \\ Doctor of Pedagogical sciences, professor \\ Dragomanov National Pedagogical University (Kyiv, Ukraine)
}

\begin{abstract}
The article represents an experimental study, which is aimed at forming the artistic and creative experience of the future choreography teacher in the process of professional training.

It is noted that questions about rethinking the social purpose of the profession of choreography teacher deserve special attention on the modern development of artistic education and updating its content, because exactly he is able to implement socially significant innovations creatively and respond mobile to the cultural demands of the time. It is emphasized that the formation of artistic and creative experience should be directed to the development of the future choreography teacher the need in communication with works of art through perception and performance interpretation, as well as valuable attitude to them; motivated gain of knowledge in the area of choreographic art and features of its expressive means as a basis for creation of choreographic images; the development of the ability to perceive artistic images in the area of choreographic art and the skills to apply the acquired artistic and creative experience consciously for in-depth mastery of choreographic works, which will contribute to the personal development of the future teacher in the vector of professional activity. Taking into account all these features requires the effective use of creative tasks and active methods, their disclosure as a mean of improving and optimizing the process of professional learning.

Key words: artistic education, student-choreographer, performing activity, professional training, artistic and creative tasks, methods.
\end{abstract}

Актуальність дослідження. Сучасний стан фахової підготовки педагогахореографа характеризується загостренням певних суперечностей між професійною діяльністю випускника вищого педагогічного навчального закладу та новими вимогами до іiі забезпечення. Відтак провідним завданням підготовки майбутнього фахівця стає формування компетенцій, які проявляються у здатності оригінально мислити, яскраво висловлювати свої думки, знаходити неординарні рішення у складних ситуаціях.

Ця проблема останнім часом досить глибоко і всебічно розроблялася сучасними психологами. Головною ознакою творчої особистості вчені (Н. Вишнякова, А. Матейко, В. Моляко, В. Романець, В. Рибалка) вважають творчі якості, тобто індивідуально- 
психологічні особливості, які відповідають вимогам творчої діяльності та ії успішного здійснення. У їх дослідженнях підкреслюються такі риси творчої особистості як багатство фантазії та інтуїції, здатність виходити за межі звичайних уявлень і бачити предмети під незвичайним кутом зору, уміння вирішувати складні питання оригінальним шляхом.

Для осмислення цього феномена також важливого значення набуває думка I. Зязюна стосовно того, що особистість має усвідомлювати свою індивідуальність та виявляти іiі у власних емоційних реакціях і станах. Такі емоції вчений вважає важливою складовою творчої індивідуальності [4, с. 17-23]. У галузі педагогіки мистецтва їі підтримує С. Гільманов. Характеризуючи творчу особистість, він виділяє такі властивості як творча спрямованість, мотивація, здібності, мислення, вольові якості, котрі зумовлюють їі внутрішню активність і результативність діяльності [2, с. 11].

Екстраполюючи визначені положення у площину фахової підготовки майбутнього хореографа можна зробити висновок, що розвиток творчої індивідуальності є системною якістю, яка інтегрує в собі усі компоненти для ії функціонування як людини і фахівця. Вона грунтується на засадах культурологічної парадигми освіти і передбачає інтеграцію мистецьких знань на всіх рівнях хореографічного навчання.

3 позицій нашого дослідження особливого значення набувають праці теоретикометодологічного спрямування (Л. Андрощук, Т. Благова, I. Герц, . Гутник, С. Забредовський, С. Зубатов, О. Пархоменко, О. Петрик, А. Підлипська, Ю. Ростовська, Т. Сердюк, О. Таранцева, П. Фриз, Л. Цветкова, Д. Шариков, В. Шкоріненко та інші), у яких підкреслюється, що на сучасному етапі художньо-хореографічної освіти вагомого значення набуває підготовка студентів як кваліфікованих спеціалістів, покликаних поширювати високохудожні зразки мистецтва, розвивати естетичні смаки учнівської молоді. Для цього їм необхідно набувати власного художньо-творчого досвіду.

Врахування основних положень науковців в галузі психології та педагогіки мистецтва дозволило розробити методику формування художньо-творчого досвіду майбутнього вчителя хореографії у процесі фахового розвиток у майбутнього вчителя хореографії потреби у спілкуванні з творами мистецтва через сприймання та виконавську інтерпретацію, а також ціннісне ставлення до них; усвідомлення важливості власної фахової підготовки на художньо-творчих засадах; 2) вмотивоване набуття знань в галузі 
хореографічного мистецтва та особливостей його виразних засобів, а також на різні твори мистецтва як основи для створення хореографічних образів; 3) розвиток здатності сприймати художні образи в галузі хореографічного мистецтва та умінь свідомо застосовувати набутий художньо-творчий досвід для поглибленого опанування хореографічних творів, що сприятиме особистісному самоудосконаленню майбутнього вчителя у векторі професійної діяльності.

Отже, сформованість художньо-творчого досвіду майбутнього вчителя хореографії має відбуватися в результаті комплексної фахової підготовки, спрямованої на розвиток хореографічного мислення. В ній актуалізується полікультурний вектор пізнання мистецтва, а також художньо-творча діяльність, яка проявляється у прагненні збагачувати й урізноманітнювати власний творчий пошук (виконавський, художньоаналітичний тощо), а також формується здатність застосовувати власні знання та уміння в майбутній педагогічній творчості.

Ми усвідомлювали, що така робота вимагає тривалого часу, тому в нашому експериментальному дослідженні вона здійснювалася протягом трьох етапів (спонукально-орієнтувального, рефлексивно-інформативного, творчокомунікативного), кожен з яких мав свою мету і завдання, а також передбачав залучення спеціально визначених педагогічних умов.

На першому етапі були визначені шляхи формування художньо-творчого досвіду студентів-хореографів 3 різною довузівською підготовкою. Для цього їм були запропоновані нескладні завдання творчого характеру: самостійно, або звертаючись за допомогою до викладача-хореографа, підготувати і виконати танцювальні етюди, які б максимально продемонстрували хореографічний текст (образну пантоміму, виразну пластику тіла, міміку і лексику), розкривали власні виконавсько-пластичні й творчі можливості, демонстрували фахову грамотність та ерудованість у хореографічновиконавській діяльності, артистизм тощо. Застосування творчих завдань передбачало колективну, парну або індивідуальну діяльність студентів-хореографів, які демонстрували навички постановки

тулуба, ніг, рук, голови; володіння виконавськими техніками та прийомами.

Виконавцям наступних хореографічних етюдів необхідно було показати не тільки техніку виконання, а й емоціï, наприклад: гнів, страх, радість, здивування. Варіантом 
цього завдання було створення засобами хореографії різних образів та розкриття їх характерних особливостей.

За другим завданням педагог запропонував, після розгляду скульптурного або живописного портрету, створити власний хореографічний образ. При цьому необхідно було зробити ретельний відбір музичного матеріалу, використовуючи твори українських або зарубіжних композиторів. Зокрема студенти намагалися самостійно визначити: твори яких композиторів, яких жанрів найбільш повно відповідають уявним образам i будуть допомагати їм у творчому вираженні.

Більш складним завданням для студентів стало створення та виконання безсюжетного етюду. В номері, в якому немає сюжету, існує цілий каскад технічно складних рухів, вони логічно пов'язуються і складають єдине ціле, єдину розвиваючу фразу або речення. Для виконання цих етюдів студентам пропонувалося підібрати відповідний музичний матеріал, а також використовувати танцювальні пози, жести, лексику за власним бажанням.

На цьому етапі для вивчення нового танцювального матеріалу та його відпрацювання ми пропонували студентам записувати свою роботу на відеокамеру 3 подальшим переглядом відеоматеріалів. Спільний аналіз помилок, коректні зауваження педагога та самостійний пошук студентами своїх недоліків у виконанні сприяли продуктивній праці на заняттях хореографії. Вони намагалися коригувати свою діяльність і добиватися нових успіхів.

Цікавим завданням для майбутніх фахівців стало створення власної творчовиконавської візитки «Моє танщ̧ювальне selfie». Зокрема, майбутніми фахівцями (самостійно або звертаючись за допомогою до викладача з фахових дисциплін) були підготовані й представлені на експертизу своїм товаришам танцювальні образи конкретного характеру людини, які проявлялися у діях та вчинках виконавця відповідно до задуманої драматургії. Крім того, студентам було запропоновано через імпровізацію хореографічного твору охарактеризувати себе, тобто виконати етюд таким чином, щоб кожний глядач мав можливість уявити портрет хореографа-виконавця. Під час виконання таких імпровізацій майбутні вчителі хореографії намагалися акцентувати увагу на переважних рисах свого темпераменту і характеру, виконавських й професійних якостях. Після демонстрації етюдів відбувалося колективне обговорення його 
особливостей, оригінальності, творчих знахідок, самовираження у процесі виконання хореографічних творів.

В умовах дефіциту навчального часу доцільним виявилось самостійне виконання студентами інформаційно-пізнавальних завдань: охарактеризувати історичні етапи розвитку теорії та методики хореографічного навчання; обгрунтувати теоретикометодичні досягнення в галузі хореографії; визначити провідні педагогічні ідеї та принципи роботи А. Ваганової; ознайомитись 3 основними порадами видатних хореографів Ж. Новера, Р. Захарова, П. Вірського, Л. Цветкової та ін.

Аналіз отриманих відповідей студентів засвідчив доцільність даного напрямку роботи, адже вони ознайомились з працями В. Костровицької «100 уроків класичного танцю», А. Писарева «Школа класичного танцю», Р. Захарова «Искусство балетмейстера», В. Никитина «Модерн-джаз танец», К. Василенка «Лексика українського народно-сценічного танцю», С. Зайцева «Основи народно-сценічного танцю», Т. Ніколаєва «Історія українського костюма», А. Шевчук «Дитяча хореографія» тощо, і виявили, що виконання різних за складністю інформаційно-пізнавальних завдань творчого спрямування стало основою для розвитку аналітичного мислення, інтелекту, активізації їх творчих можливостей, пізнавальних умінь і навичок.

Експериментальна робота на даному етапі була спрямована на формування у майбутніх фахівців здатності критично оцінювати свої досягнення в галузі балетмейстерської роботи, характеризувати свої можливості й досягнення як хореографа-виконавця, а також визначити і обрати найбільш доцільні засоби подолання існуючих недоліків.

Студенти продемонстрували творчий розвиток у всіх напрямках фахової підготовки і виявили інтерес до здобуття знань 3 історії, теорії та методики хореографічного навчання. Спрямованість цих завдань не тільки на виконавську, а й на просвітницьку діяльність, зумовила виникнення творчої комунікації між усіма студентами та сприяла формуванню художньо-творчого досвіду майбутніх вчителів хореографії.

Завдання другого етапу експериментальної роботи передбачали формування компетентнісного ставлення студентів до професії хореографа, збагачення студентів знаннями з методики хореографічного навчання з метою підвищення їх виконавського 
рівня; активізація естетико-емоційної сфери; розвитку у майбутніх учителів хореографії здатності до рефлексії, що дозволить у майбутньому осмислити свої думки, емоційні стани та виконавські дії.

На даному етапі було з'ясовано, що більшість студентів захоплюються сучасними ритмами, характерними для «джаз-модерн» танців. Коли потрібно було донести ідею танцю до студентів, впливати на їх розум і почуття, ми використовували метод переконання.

Необхідність формування художньо-творчого досвіду студентів на другому етапі знайшла своє відображення у роботі з навчально-творчими завданнями, основною метою яких було створення творчої ситуаџї̈. Специфічною особливістю творчих завдань $€$ відсутність будь-яких правил, що ведуть до їх вирішення й наштовхують на нові шляхи їх розв'язання.

Робота з творчими завданнями вимагає активного опанування та засвоєння знань та вмінь під час розкриття творчих можливостей студента. Адже він підсвідомо активізує такі важливі для творчості психічні процеси як мислення, творча уява, увага, перетворюючи одні образи на інші.

Творчі завдання наділяють кожного студента можливістю видозмінювати свій результат у процесі розв'язання завдань, відступати від шаблону та одержувати оригінальні творчі продукти. Їх використання на практичних заняттях концертносценічного практикуму, мистецтва балетмейстера, постановки концертних номерів тощо, впливає на формування мотиваційної сфери майбутніх педагогів-хореографів, пробуджує потребу в творчості й самовдосконаленні, а також стимулює самостійність й організованість, виховує відповідальність та працелюбність. Прикладами таких індивідуальних навчально-творчих завдань можуть бути: «Музика підкаже», метою якого є формування у студентів навичок імпровізації танцювальних рухів, розвиток музикальності, творчості; «Вигадай сам», який активізує танцювальну творчість, закріплює вміння виконувати танцювальні рухи, виявляє здатність вільно оперувати набутим досвідом в ігрові формі. При цьому ігрові завдання з елементами змагання додають зацікавленості, мотивують до їх вирішення. Адже, як відомо з чисельних наукових психолого-педагогічних досліджень, змагання між учасниками, які виконують спільне завдання, сприяє розвитку творчих сил, підвищує активність та інтерес студентів 
до діяльності, а також стимулює відсталих до рівняння успішніших студентів. Ефективність таких форм творчої роботи багато в чому визначається характером взаємин між студентами, а також між студентами та викладачем.

Ще один вид навчально-творчих завдань передбачав знайомство студентів із творчістю відомих хореографів, А. Дункан [5; 9], Г. Уланової, М. Есамбаєва, М. Плісецької, М. Цискарідзе тощо, які створювали свій унікальний мінітеатр. Студентам пропонувалося подивитися їх виконання у відеозапису й охарактеризувати виступи, визначаючи особливості пластики, темпераменту, техніки тощо. Виконання цього завдання передбачало інтеграцію знань у різних жанрах хореографічного мистецтва, використання аналогій, асоціацій, художніх узагальнень, емоційно-чуттєвих зусиль.

За свідченням студентів, така форма роботи є цікавою і плідною, адже вчителю хореографії у своїй професійній діяльності доводиться не тільки виконувати хореографічні твори, але й здійснювати їх художньо-педагогічну інтерпретацію.

Іншою можливістю реалізувати себе в специфічній формі творчого завдання було застосування різних імпровізацій, під час яких у студентів розвивалися вміння керувати власними емоційними станами, збагачувалася творча уява, мислення, здатність до створення оригінальних ідей. Адже в результаті імпровізації народжується власний витвір мистецтва, виконаний в атмосфері творчої свободи, яка відкриває перед майбутнім педагогом-хореографом нові горизонти на шляху формування та примноження його художньо-творчого досвіду.

Так, досліджуючи проблему розвитку творчої індивідуальності майбутнього вчителя хореографії, Л. Андрощук класифікувала хореографічну імпровізацію таким чином: за кількістю суб'єктів творчої діяльності (групові та індивідуальні); за метою реалізації навчально-виховного процесу (навчальні, розвивальні творчої фантазії та ін.); за характером стимулюючих засобів (образні, музичні, «живий живопис», «жива скульптура», наслідування та ін.); за тематикою (вільна тема, пропонована тема) [1, с. $15]$.

Відповідно до експериментальної методики на даному етапі студентам було запропоновано розробити ряд творчих завдань, а саме: виконуючи заздалегідь вивчений танцювальний етюд, за командою педагога швидко замінити вивчений рух на інший, або 
розучування певної кількості рухів, не залежно від їх походження. Після цього студентам було необхідно впізнати їх національну приналежність, вибрати рухи однієї національності, доповнити їх своїми рухами й на цій основі створити етюд.

Аналізуючи представлені студентами завдання ми побачили, що вони уважно ставляться до рефлексії власних досягнень і невдач, намагаються визначати проблеми у навчанні та інтерпретації хореографічних творів. Разом з тим, більшість 3 них ще потребує значної допомоги педагога.

Студенти в експериментальній роботі на даному етапі провели конструктивне обговорення з товаришами і викладачами різних (нерідко суперечливих) думок стосовно феномену інтерпретації хореографічних творів, намагалися довести свою позицію на конкретних прикладах, а також визначили і обирали найбільш доцільні засоби подолання існуючих недоліків.

Основою третього (творчо-комунікативного) етапу формувального експерименту стало розширення, поглиблення та закріплення творчих умінь і навичок, набутих на перших двох етапах експерименту. Відповідно до мети нашого дослідження передбачалося продовжити вивчення методичної літератури з питань хореографічної підготовки, в якій основна увага приділялася проблемі художньо-творчого становлення фахівця, ускладнення танцювальної лексики, що зумовило зростання обсягу та інтенсивності навантажень, розширився структурний склад танцювальних рухів. Різносторонню хореографічну підготовку студенти отримали переглядаючи мультимедійні відео-уроки, фільми, присвячені балетним виставам і видатним танцівникам, майстер-класи тощо.

Завдяки принщипу поєднання традищій $i$ новаторства на третьому етапі було продовжено оволодіння навичками поєднання хореографічного мистецтва з музикою, що сприяє симфонізації танцю, а з драмою - поглибленню драматичної дієвості танцю і пантоміми. Навчання мистецтву танцю вимагає від педагога грунтовних знань народних традицій, постійного прагнення до оновлення танцювальних форм і стилів, створення нових технік та композицій для концертно-сценічної діяльності.

Дієвим на даному етапі стало використання методу наслідування майстрів, який описаний професором О. Щолоковою у роботі «Основи професійної художньоестетичної підготовки майбутнього вчителя» [8]. Цей метод став змістовим 
продовженням попередніх завдань, адже передбачав ознайомлення, вивчення та аналіз творчості видатних хореографів. Зусилля студентів зосереджувались на оволодінні такими уміннями і навичками: максимально розвивати природні здібності танцівника, стимулювання мотивації, поєднання теоретичних знань із практичною діяльністю, засвоєння танцювальної лексики і манери виконання, застосування аудіовізуальних засобів, ілюстративно-художніх матеріалів у концертно-сценічній діяльності.

Особлива увага на даному етапі також приділялася художньо-творчим завданням, які вимагали самостійного вирішення. Прикладом такого завдання стало створення танцю на основі народних традицій засобами театралізації. Студенти могли самостійно розподілити ролі, створити драматургію танцю, зробити сценічне оформлення і декорації, підібрати костюми. Сюжети для танців пропонувалося вибирати 3 джерел народної художньої творчості, наприклад, свята чи обряда (Стрітення, Івана Купала, коляда, веснянки - Україна, дожинки, кудельниці - Білорусія, Мерцишор Румунія), тощо. Танець розвивається, відображаючи еволюцію життя людей, як складний процес перетворення традицій, доповнення їх новими елементами.

Для ускладнення завдання студентам пропонувалось стилізувати свій хореографічний номер. Стилізація народного танцю, полягає в умінні грамотно поєднувати сучасні, акробатичні рухи і трюки з істинно народними рухами [3]. При цьому оцінювалися: відповідність танцювальної лексики, костюма та музичного оформлення; оригінальність сюжету та стилізації; передача художнього образу, характеру та манери танцю; техніка виконання, акторська майстерність, артистизм. Це завдання дає можливість виконавцю повністю проявити свою творчість і креативність, втілити найсміливіші балетмейстерські ідеї. Презентація усіх завдань супроводжувалася створенням власної концепції виконання. Студенти висловлювали свої думки, щодо художніх й позахудожніх асоціації, які виникали у них у процесі інтерпретації хореографічних творів.

У даному випадку ми користувалися позицією А. Славської [7], яка розглядає ознаки індивідуальних особливостей інтерпретування у таких своєрідних дихотомічних зв'язках: абстрактність-конкретність, суб'єктивізм-об'єктивізм, контекстністьфрагментарність тощо. 
Важливо зазначити, що представлені пари зв’язків студенти використовували для побудови виконавської інтерпретації як хореографічних творів відомих митців, так і власних композицій. Використання таких понять допомогло студентам більш грунтовно підходити до інтерпретації хореографічного твору: не зупинятися на усталених прикладах, а здійснювати самостійну інтерпретаційну роботу під час підготовки власних хореографічних проектів.

Великого значення на цьому етапі надавалось самостійній роботі, яка є однією 3 складових формування художньо-творчого досвіду студентів. Якщо на перших двох етапах ця роботи відбувалася з постійною консультацією педагога, то на третьому етапі студентам була надана повна самостійність як у виборі музики, сюжету, так і методів опрацювання танцювального номера.

Для домашніх завдань студентам пропонувалося підготувати хореографічні композиції з використанням літературного першоджерела (казки, легенди, пісні), народних свят та традицій. Для цього їм необхідно було зробити ретельний відбір характерних образів, персонажів, а також підібрати відповідну музику, лексику, костюми, реквізит тощо.

Аналіз результатів дослідно-експериментальної роботи на цьому етапі показав, що включення студентів у різні види виконавської та балетмейстерської діяльності завдяки використанню творчих завдань, а також системність і послідовність у вивченні навчально-методичної та мемуарної літератури 3 проблем хореографії сприяли залученню до національно-культурних цінностей, підвищенню працездатності, що забезпечує цілеспрямований розвиток життєво-важливих духовних, інтелектуальних і виконавських умінь для сформованості їх художньо-творчого досвіду. Разом з цим у процесі творчої діяльності студентів-хореографів, збагачувався мистецький тезаурус, активізувалися виконавські якості фахового спрямування, покращилися уміння фахового спілкування, розширилася комунікативно-емоційна сфера, реалізувались їх творчі та педагогічні ідеї.

Висновки. Проведене експериментальне дослідження показало, що майбутні вчителі хореографії навчилися використовувати власний творчий потенціал у різних видах художньо-педагогічної діяльності. В їх діях зросла частка самостійності та 
відповідальності за результати своєї навчальної роботи, активізувався інтелектуальний потенціал, збагатилась їх хореографічна культура.

Виконання художньо-творчих завдань різного плану сприяло підвищенню якості хореографічного навчання, що в свою чергу посприяло підвищенню рівня фахової компетентності студентів. Студенти почали розуміти важливість набутих знань для своєї майбутньої професійної діяльності. Вони стали більш вільно використовувати їх у наступних балетмейстерських роботах та творчих проектах, зрозуміли важливість постійного поповнення своїх знань для професійного зростання.

Таким чином, завдяки застосуванню творчих завдань і активних методів навчання навчальна діяльність студентів набула універсального характеру. В ній поєдналися інформаційна, освітня, дослідницька i праксеологічна функції, які дозволили організувати фахове навчання майбутніх педагогів-хореографів таким чином, щоб пролонговане формування їх досвіду в галузі художньо-творчої діяльності стало каталізатором якості освіти у вищому навчальному закладі.

\section{References}

1. Androshchuk L. M. Tantsyuval'na improvizatsiya yak zasib rozvytku tvorchoyi osobystosti maybutn'oho vchytelya khoreohrafiyi [Dance improvisation as a means of developing the creative personality of a future choreography teacher]. URI : http://dspace.udpu.org.ua:8080/jspui/bitstream/6789/1571/1/\%.pdf.

2. Hyl'manov S. Tvorcheskaya yndyvydual'nost' uchytelya: uchebnoe posobye [Creative personality of the teacher: tutorial]. Tyumen, 1975. $167 \mathrm{p}$.

3. Zakharov V. M. Sovremennaya kontseptsyya razvytyya russkoy narodnoy khoreohrafyy $v$ kontekste ustnogo tvorchestva i khudozh. promyslov [The modern concept of the development of Russian folk choreography: in the context of oral creativity and artistic crafts] : avtoref. dys. kand. spets. 24.00.01. Mynsk, 2003. 43 p.

4. Zyazyun I. A. Estetychni zasady rozvytku tvorchoyi osobystosti. Mystetstvo u rozvytku osobystosti [Art in the development of specialties] : monohrafiia. Chernivtsi : Zelena Bukovina, 2006.

5. Pet'ko L. V. Anhliys'ka mova dlya studentiv-khoreohrafiv. Dydaktychnyy material dlya praktychnykh zanyat' ta samostiynoyi roboty studentiv z inozemnoyi movy zi spetsial'nosti 6.020202 "Khoreohrafiya» : navch. posibnyk dlya studentiv ta vykladachiv VNZ [English for choreographers. Didactic material for practical classes and independent work of students in a foreign language in the specialty 6.020202 "Choreography"]. Kyiv : Talkom, 2016. 169 p. : il., portr.

6. Pet'ko L. V. Estetychni priorytety studentiv ta vykhovannya estetychnoyi kul'tury maybutnikh khoreohrafiv [Aesthetic priorities of students and education of aesthetic culture of 
future choreographers]. Pedahohichnyy al'manakh : zb. nauk. pr. Kherson : KVNZ "Khersons'ka akademiya neperervnoyi osvity", 2017. Vol. 34. Pp. 35-41.

7. Slavskaya A. N. Lychnost kak subekt interpretatsyy [Personality as a subject of interpretation]. Dubna: Fenyks, $240 \mathrm{p}$

8. Shcholokova O. P. Kontseptual'ni zasady suchasnoyi mystets'ko-pedahohichnoyi osvity $v$ Ukrayini [Conceptual principles of modern art and pedagogical education in Ukraine.]. Mystetska osvita u vymirakh suchasnosti:problemy teoriyi ta praktyky. 2014. Pp. 22-47.

9. Pet'ko Lyudmila, Shpota Yevgenia. Isadora Duncan and Sergey Esenin. Intellectual Archive. 2014. January. Volume 3. Number 1. Toronto : Shiny Word Corp. Pp. 82-88.

\section{Translation of the Title, Abstract and References to the Author's Language}

УДК 378.016-051:793.3

Максименко В. І., Щолокова О. П. Методика формування художньотворчого досвіду майбутнього вчителя хореографії у процесі фахового навчання.

Представлено експериментальне дослідження, спрямоване на формування художньо-творчого досвіду майбутнього вчителя хореографії в процесі фахової підготовки. Зазначається, що на сучасному розвитку мистецької освіти та оновлення їі змістової сторони особливої уваги заслуговують питання щодо переосмислення суспільного призначення професії вчителя хореографії, оскільки саме він здатний творчо впроваджувати соціально-значущі новації і мобільно реагувати на культурні вимоги часу. Підкреслюється, що формування художньо-творчого досвіду необхідно спрямувати на розвиток у майбутнього вчителя хореографії потреби у спілкуванні 3 творами мистецтва через сприймання та виконавську інтерпретацію, а також ціннісне ставлення до них; вмотивоване набуття знань в галузі хореографічного мистецтва та особливостей його виразних засобів як основи для створення хореографічних образів; розвиток здатності сприймати художні образи в галузі хореографічного мистецтва та умінь свідомо застосовувати набутий художньо-творчий досвід для поглибленого опанування хореографічних творів, що сприятиме особистісному удосконаленню майбутнього вчителя у векторі професійної діяльності. Урахування окреслених особливостей вимагає ефективного використання творчих завдань і активних методів, їх розкриття як засобу удосконалення і оптимізації процесу фахового навчання.

Ключові слова: мистецька освіта, студент-хореограф, виконавська діяльність, фахова підготовка, художньо-творчі завдання, методи.

\section{Лimepamypa}

1. Андрощук Л. М. Танцювальна імпровізація як засіб розвитку творчої особистості майбутнього вчителя хореографії. URI : http://dspace.udpu.org.ua:8080/jspui/bitstream/6789/1571/1/\%.pdf.

2. Гильманов С. Творческая индивидуальность учителя: учебное пособие. Тюмень. 1995. 167 с.

3. Захаров В. М. Современная концепция развития русской народной хореографии: (В контексте устного творчества и худож. промыслов) : автореф. дис. канд. культурологии : спец. 24.00.01. Минск, 2003. 43 с. 
4. Зязюн I. А. Естетичні засади розвитку творчої особистості // Мистецтво у розвитку особистості : монографія / за ред. Н. Г. Нічкало. Чернівці : Зелена Буковина. 2006.

5. Петько Л. В. Англійська мова для студентів-хореографів. Дидактичний матеріал для практичних занять та самостійної роботи студентів з іноземної мови зі спеціальності 6.020202 «Хореографія» : навч. посібник для студентів та викладачів ВНЗ. Київ : Талком, 2016. 169 с. : іл., портр.

6. Петько Л. В. Естетичні пріоритети студентів та виховання естетичної культури майбутніх хореографів. Педагогічний альманах : зб. наук. пр. ; редкол. В. В. Кузьменко та ін. Херсон : КВНЗ "Херсонська академія неперервної освіти", 2017. Вип. 34. С. 35-41.

7. Славская А. Н. Личность как субъект интерпретации. Дубна : Феникс+. 2002. $240 \mathrm{c}$.

8. Щолокова О. П. Концептуальні засади сучасної мистецько-педагогічної освіти в Україні. Мистеиька освіта у вимірах сучасності:проблеми теорії та практики. Дніпропетровськ, 2014. С. 22-47 с.

9. Pet'ko Lyudmila, Shpota Yevgenia. Isadora Duncan and Sergey Esenin. Intellectual Archive. 2014.- January. Volume 3. Number 1. Toronto: Shiny Word Corp. Pp. 82-88. 